$\left.\begin{array}{c}\text { BIODIK: Jurnal IImiah Pendidikan Biologi } \\ \text { ISSN 2580-0922 (online), ISSN 2460-2612(print) } \\ \text { Volume 7, Nomor 02, Tahun 2021, Hal. 216-226 } \\ \text { Available online at: } \\ \text { https://online-journal.unja.ac.id/biodik }\end{array}\right)$ BIODIK

Research Article

\title{
Rekonstruksi Desain Kegiatan Laboratorium Berbasis ANCORB Pada Materi Hereditas
}

(Reconstruction Of ANCORB-Based Laboratory Activities Design on Heredity Materials)

\author{
Ari Kusnandar Maulana*, Bambang Supriatno, Sri Anggraeni
}

Program Studi Pendidikan Biologi, Fakultas Pendidikan Matematika dan IImu Pengetahuan Alam

Universitas Pendidikan Indonesia

JI. Dr. Setiabudi No. 229, Bandung, Indonesia

${ }^{*}$ Corresponding author: arikmaulana@upi.edu

\begin{tabular}{|c|c|}
\hline Informasi Artikel & ABSTRACT \\
\hline $\begin{array}{l}\text { Submit: } 22-03-2021 \\
\text { Diterima: } 30 \text { - } 05-2021 \\
\text { Dipublikasikan: } 25-06-2021\end{array}$ & $\begin{array}{l}\text { Experiment method is suitable learning method for biology's learning. } \\
\text { Experiment method requires a guide in the form of student worksheets, so the } \\
\text { experiment method can be implemented and in accordance with the objectives } \\
\text { of learning. This research seeks to (1) obtain an overview concerning the } \\
\text { suitability of practicum objectives stated in DKL with the basic competences } \\
\text { stated in the curriculum, (2) obtain an overview concerning the suitability of } \\
\text { practicum objectives with steps in DKL, (3) obtain an overview concerning the } \\
\text { practicum objectives, concepts/principles, in DKL, (4) find out whether the steps } \\
\text { in DKL guide students to perform knowledge construction. This research } \\
\text { implemented descriptive qualitative method with ANCORB stages, consisting of } \\
\text { (1) Analysis, (2) Trial, and (3) Reconstruction. The analysis was carried out by } \\
\text { paying attention to conceptual, practical, and knowledge construction aspects. } \\
\text { The research object consisted of } 8 \text { LKPDs on genetics buttons practicum } \\
\text { sourced from various books made by teachers, selected through purposive } \\
\text { sampling. The research results revealed that those LKPDs are not feasible to } \\
\text { use, do not meet the ideal score, and do not meet the criteria stated on diagram } \\
\text { fee. }\end{array}$ \\
\hline & $\begin{array}{l}\text { Key words: Laboratory Activities, Heredity, Genetic Buttons, Laboratory } \\
\text { Activities Analysis }\end{array}$ \\
\hline Penerbit & ABSTRAK \\
\hline $\begin{array}{l}\text { Program Studi Pendidikan Biologi } \\
\text { FKIP Universitas Jambi, } \\
\text { Jambi- Indonesia }\end{array}$ & $\begin{array}{l}\text { Metode praktikum merupakan metode belajar yang sangat tepat untuk } \\
\text { pembelajaran biologi. Dalam praktikum biologi diperlukan panduan berupa } \\
\text { lembar kerja peserta didik agar praktikum dapat dilaksanakan dan sesuai } \\
\text { dengan tujuan pembelajaran Tujuan dari penelitian ini adalah (1) memperoleh } \\
\text { gambaran mengenai kesesuaian tujuan praktikum yang terdapat pada DKL } \\
\text { dengan kompetensi dasar pada kurikulum, (2) mengetahui gambaran } \\
\text { kesesuaian antara tujuan praktikum dengan langkah-langkah pada DKL, (3) } \\
\text { mengetahui gambaran mengenai tujuan praktikum prinsip/konsep pada DKL, } \\
\text { (4) untuk mengetahui apakah langkah-langkah pada DKL sudah dapat } \\
\text { mengarahkan siswa terhadap kontruksi pengetahuan. Metode yang digunakan } \\
\text { dalam penelitian ini adalah deskriptif kualitatif dengan tahapan ANCORB, yaitu } \\
\text { (1) Analisis, (2) Uji Coba, (3) Rekontruksi. Analisis dilakukan dengan } \\
\text { memperhatikan } 3 \text { aspek, yaitu aspek konseptual, aspek praktikal dan aspek } \\
\text { kontruksi pengetahuan. Objek penelitian menggunakan } 8 \text { LKPD mengenai } \\
\text { praktikum kancing genetika yang berasal dari berbagai buku dan yang dibuat } \\
\text { oleh guru disekolah yang dipilih secara purposive sampling. Berdasarkan hasil }\end{array}$ \\
\hline
\end{tabular}


analisis yang telah dilakukan terhadap 8 LKPD belum layak digunakan dan tidak memenuhi skor ideal dan belum memenuhi kriteria pada diagram fee.

Kata kunci: Kegiatan laboratorium, Hereditas, Kancing Genetika, Analisis Kegiatan Laboratorium

\section{(i)(2)}

BY Ne SA

This BIODIK : Jurnal IImiah Pendidikan Biologi is licensed under a CC BY-NC-SA (Creative Commons Attribution-ShareAlike 4.0 International License)

\section{PENDAHULUAN}

Belajar (learning) merupakan kata yang sampai saat ini menjadi topik di dalam dunia pendidikan. Karena untuk mendefinisikan apa itu belajar sangat sulit didefinisikan secara pasti (Abidin, 2016). Belajar dapat diartikan sebagai perubahan perilaku atau potensi perilaku yang relatif permanen yang berasal dari pengalaman dan tidak bisa di nisbahkan ke dalam temporary body states (keadaan tubuh temporer) seperti keadaan sakit, keletihan atau obat-obatan (Hergenhahn \& Olson, 2012). Proses belajar dilakukan untuk memperoleh pengetahuan dan keterampilan yang dapat diimplementasikan dalam kebiasaan dan tingkah laku (Slameto, 2015). (Tawil \& Liliasari, 2013) menjelaskan bahwa pembelajaran di abad ke-21 harus dapat mengarahkan siswa untuk memiliki kemampuan berpikir tingkat tinggi atau yang sering disebut dengan high order thinking skill (HOTS). Kemampuan berpikir tingkat tinggi dapat diartikan sebagai kemampuan yang dimiliki oleh seseorang untuk berpikir kritis, berpikir logis, berpikir reflektif dan juga berpikir kreatif (King et al., 2017). Sejalan dengan pendapat tersebut, (Anderson \& Krathwohl, 2015) menjelaskan bahwa high order thinking pada taksonomi bloom dimulai pada kemampuan menganalisis (C4), mengevaluasi (C5) dan mencipta (C6).

Pembelajaran sains khususnya biologi sudah mengalami banyak perkembangan, biologi yang pada awalnya dianggap sebagai mata pelajaran yang hanya dibebani konsep saja telah berubah menjadi mata pelajaran yang harus melibatkan siswa dalam pengalaman belajar (learning experience) (Rustaman, 2017). Pengalaman bejalar tersebut harus mengarahkan siswa terhadap konsep nyata yang berada di lingkungan sekitarnya sehingga pembelajaran lebih bermakna (Aisya et al., 2016). Selain itu, biologi memiliki karakteristik yang khas dimana proses pembelajarannya harus bersifat berpusat pada siswa (student centeter), autitentik serta dapat melatih kemampuan siswa dalam mengorganisasi, mengolah, mengkomunikasikan serta menginterpresikan data hasil observasi (Kurniasih et al., 2020). Untuk mencapai tujuan yang terdapat dalam karakteristik biologi tersebut, maka diperlukan suatu metode pembelajaran yang cocok, yaitu dengan menggunakan metode praktikum.

Praktikum merupakan kegiatan belajar yang dimana melibatkan siswa dalam mengobservasi dan memanipuasi objek dari materi yang mereka pelajari (Millar, 2004). Kegiatan praktikum dibutuhkan untuk melatih keterampilan dasar siswa dalam bekerja di laboratorium. Dengan adanya praktikum siswa dilatih untuk mengembangkan kemampuan kognitif, psikomotor serta afektif (Wahidah et al., 2018). Praktikum sering disebut dengan "practical work" daripada "laboratory work", karena tempat untuk melakukan praktikum tidak hanya terbatas di laboratorium saja, melainkan bisa dimana saja sesuai dengan keperluan dan karakteristik dari materi pembelajaran yang dilakukan (Millar, 2004) Untuk melaksanakan praktikum yang dapat mengarahkan siswa untuk merekontruksi pengetahuan dan melatih kemampuannya, maka diperlukan suatu acuan atau pedoman dalam melaksanaan praktikum 
berupa desain kegiatan laboratorium (DKL). Desain kegiatan laboratorium (DKL) merupakan suatu perangkat pembelajaran yang digunakan dalam praktikum. Astika et al., (2020) menjelaskan ada 2 prinsip utama dalam pembuat DKL, (1) tujuan praktikum harus sesuai dengan apa yang akan dipelajari oleh siswa, (2) langkah-langkah kerja yang disusun dalam DKL harus sesuai dengan tujuan praktikum sehingga siswa dapat memahami objek/kajian dari materi yang dipelajari.

Pada kenyaatannya, pembuatan DKL terkadang terkendala oleh beberapa masalah yang menyebabkan DKL tersebut belum bisa mengarahkan siswa untuk terlibat dalam kegiatan praktikum yang benar. Dalam penelitian (Supriatno, 2018) menyatakan bahwa kemampuan guru untuk mengembangkan kegiatan laboratorium hanya baru sekitar 53\% saja. Hal tersebut disebakan oleh beberapa faktor (1) tujuan praktikum lebih menekankan kepada aspek kognitif, (2) materi yang disajikan dalam DKL tidak menyesuaikan dengan aspek kemampuan siswa, (3) prosedur/langkah kerja yang terdapat dalam DKL tidak terstruktur yang pada akhirnya menyebabkan kebingunan terhadap siswa (Supriatno, 2013). Berdasarkan penjelasan tersebut, maka diperlukan suatu acuan atau patokan dalam pembuatan DKL yang bisa mengarahkan siswa untuk mengontruksi pengetahuan, mengembangkan keterampilan dasar eksperimen, dan juga memberikan pembelajaran yang bermakna.

Materi hukum pewarisan sifat (hereditas) merupakan materi pada mata pelajaran biologi yang sering menyebabkan miskonsepsi terhadap siswa, pada materi hereditas terdapat konsep mengenai persilangan dihibrid dan monohibrid. Materi hibridisasi tersebut sering dilakukan dengan kegiatan praktikum dengan menggunakan sebuah alat yang disebut dengan kancing genetika. Pada praktikum kancing genetika siswa mempelajari istilah-isitlah seperti parental, gamet, fenotip, genotip, alel, filial, rasio perbandingan melalui analogi persilangan. Pada praktikum kancing genetika, siswa terkadang mengalami beberapa kesulitan dalam mempelajari konsep-konsep hereditas, hal tersebut disebabkan karena beberapa faktor, (1) motivasi dan minat siswa terhadap materi hereditas sangat rendah, (2) kesulitan dalam menyelesaikan soal hitungan yang memerlukan beberapa tahap penyelesaian, (3) kurangnya keaktifan siswa untuk terlibat dalam proses pembelajaran (Muriani, 2017).

Berdasarkan latar belakang tersebut penulis melakukan penelitian dengan cara melakuakan uji coba dan menganalisis beberapa desain kegiatan laboratorium (DKL) yang ada dan tersebar di beberapa buku dan juga sekolah yang sering digunakan oleh guru mengenai praktikum kancing genetika. Tujuan dari penelitian ini adalah (1) memperoleh gambaran mengenai kesesuaian tujuan praktikum yang terdapat pada DKL dengan kompetensi dasar pada kurikulum, (2) mengetahui gambaran kesesuaian antara tujuan praktikum dengan langkah-langkah pada DKL, (3) mengetahui gambaran mengenai tujuan praktikum prinsip/konsep pada DKL, (4) untuk mengetahui apakah langkahlangkah pada DKL sudah dapat mengarahkan siswa terhadap kontruksi pengetahuan.

\section{METODE PENELITIAN}

Metode penelitian yang digunakan dalam penelitian ini adalah deskriptif kualitatif. Metode deskriptif kualitatif digunakan untuk menjelaskan dan menggambarkan nilai atau makna yang terdapat dalam suatu fakta atau fenomena (Sugiyono, 2017). Penelitian ini menggunakan 3 tahap yaitu (1) analisis, (2) uji coba, (3) rekontruksi, ketiga tahap tersebut disingkat menjadi ANCORB. Objek penelitian yang digunakan adalah lembar kerja peserta didik (LKPD) yang yang berasal dari beberapa buku paket dan juga LKPD mengenai praktikum kancing genetika yang dibuat oleh guru di beberapa sekolah. LKPD yang dianalisis berjumlah 8 dipilih secara purposive sampling yang berasal dari kurikulum 2006 
(KTSP) dan juga kurikulum 2013 (kurtilas). Aspek DKL yang dianalaisis meliputi aspek konseptual, aspek praktikal dan aspek kontruksi pengetahuan yang berdasarkan pada diagram vee yang dijelaskan pada penelitian (Novak \& Gowin, 1984).

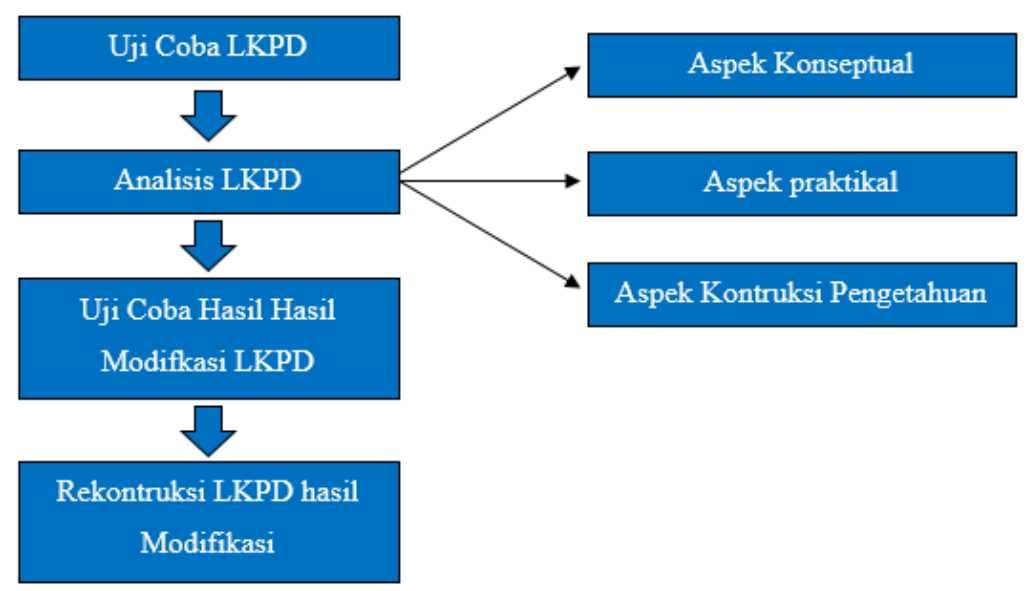

Gambar 1. Tahapan ANCORB

\section{HASIL PENELITIAN DAN PEMBAHASAN}

Untuk langkah pertama yaitu melakukan analisis terhadap $8 \mathrm{DKL}$ yang berasal dari kurikulum 2006 (KTSP) dan juga kurikulum 2013 (kurtilas) dengan memperhatikan 3 aspek, yaitu aspek konseptual, aspek praktikal dan juga aspek konstruksi pengetahuan. Untuk hasil analisis akan diuraikan sebagai berikut:

\section{Aspek Konseptual}

Analisis DKL terhadap aspek konseptual bertujuan untuk menganalisis kegiatan praktikum dengan kurikulum yang berlaku (Kurniasih et al., 2020). Pada aspek konseptual ada 2 indikator yang dianalisis, yaitu indikator relevansi (kegiatan praktikum dan kurikulum) dan juga aspek kompetensi (hands on dan minds on). Hasil analisis aspek konseptual dapat dilihat pada tabel 1.

Tabel 1. Hasil Analisis Aspek Konseptual

\begin{tabular}{|c|c|c|c|c|c|c|c|c|c|c|c|}
\hline \multirow{2}{*}{ Komponen } & \multirow{2}{*}{ Indikator } & \multirow{2}{*}{$\begin{array}{l}\text { Skor } \\
\text { maks. }\end{array}$} & \multicolumn{8}{|c|}{ DKL } & \multirow[t]{2}{*}{ Hasil } \\
\hline & & & 1 & 2 & 3 & 4 & 5 & 6 & 7 & 8 & \\
\hline \multirow{4}{*}{$\begin{array}{c}\text { Aspek } \\
\text { Relevansi } \\
\text { (Kegiatan \& } \\
\text { Kurikulum) }\end{array}$} & Kompetensi LKPD & & & & & & & & & & \\
\hline & $\begin{array}{l}\text { sesuai dengan } \\
\text { tuntutan } \mathrm{KD}\end{array}$ & 2 & 1 & 1 & 1 & 1 & 1 & 1 & 1 & 1 & $50 \%$ \\
\hline & Konten pada & & & & & & & & & & \\
\hline & $\begin{array}{l}\text { LKPD sesuai } \\
\text { dengan KD }\end{array}$ & 2 & 1 & 1 & 1 & 1 & 1 & 1 & 1 & 1 & $50 \%$ \\
\hline \multirow{4}{*}{$\begin{array}{c}\text { Aspek } \\
\text { Kompetensi } \\
\text { (Hands on \& } \\
\text { Minds on) }\end{array}$} & $\begin{array}{l}\text { Kemampuan } \\
\text { observasi }\end{array}$ & 3 & 1 & 1 & 1 & 1 & 1 & 1 & 1 & 1 & $33,33 \%$ \\
\hline & Transformasi data & 3 & 1 & 1 & 1 & 1 & 1 & 1 & 1 & 1 & $33,33 \%$ \\
\hline & Interpretasi data & 4 & 2 & 1 & 2 & 1 & 2 & 2 & 2 & 1 & $40,62 \%$ \\
\hline & $\begin{array}{l}\text { Level kemampuan } \\
\text { berpikir tingkat } \\
\text { tinggi }\end{array}$ & 3 & 1 & 0 & 0 & 0 & 0 & 0 & 0 & 0 & 4,16 \\
\hline
\end{tabular}


Berdasarkan tabel 1 pada aspek relevansi , indikator kompetensi pada LKPD dengan tuntutan kompetensi dasar (KD) pada kurikulum menunujukan bahwa $8 \mathrm{DKL}$ memiliki hasil persentase sebesar $50 \%$ karena telah memenuhi standar kompetensi minimal KD. Selanjutnya dari indikator konten pada LKPD dengan kompetensi dasar (KD) pada kurikulum menunjukan hasil presentase sebesar 50\%, karena 8 DKL yang dianalisis telah memenuhi standar minimal KD. Putri (2016) menjelaskan bahwa salah ciri dari LKPD yang baik adalah LKPD yang memiliki kompetensi dan konten yang sudah memenuhi standar tuntutan kompetensi dasar pada kurikulum. Pada aspek kompetensi terdapat hands on dan minds on. Kegiatan minds on dapat diartikan sebagai kegiatan siswa dalam menggunakan keterampilan berpikirnya selama kegiatan praktikum yang meliputi tranformasi data yang didapat berdasarkan hasil observasi, data hasil transformasi tersebut nantinya akan dianalisis dan pada akhirnya akan menghasilkan pengetahuan baru (Supriatno, 2018). Kegiatan hands on dapat diartikan sebagai kegiatan belajar yang dilakukan oleh siswa selama praktikum yang dimana siswa terlibat dalam aktifitas menggunakan alat (instrument) dan juga memanipulasi objek (manipulation of object) yang dipelajari (Holstermann et al., 2010).

Indikator kemampuan observasi menunjukan bahwa $8 \mathrm{DKL}$ yang dianalisis hanya mengarahkan siswa untuk pada kegiatan mengobservasi karakter umum dari objek/fenomena sehingga persentase hasil yang diperoleh menunjukan $33,33 \%$. Untuk indikator transformasi menunjukan bahwa 8 DKL yang dianalisis hanya mengarahkan siswa untuk menyajikan data kuantitatif yang masih sederhana, yaitu dalam bentuk tabulasi dan juga frekuensi saja, sehingga hasil persentase menunjukan 33,33\%. Indikator interpretasi menunjukan $5 \mathrm{DKL}$ mengarahkan siswa hanya membaca kompenen data saja dan 3 DKL lainnya mengarahkan siswa untuk membuat perbandingan relatif kuantitatif pada data, sehingga hasil persentase menunjukan 40,62\%. Untuk indikator level kemampuan berpikir menunjukan $1 \mathrm{DKL}$ mengarahkan pada kemampuan untuk menganalisis (C4) dan 7 DKL lainnya hanya mengarahkan pada kemampuan untuk mengaplikasikan pengetahuan matematik dasar mengenai frekuensi dan tabulasi (C3), sehingga hasil persentase nya menunjukan $4,16 \%$.

\section{Aspek Praktikal}

Analisis terhadap aspek praktikal memiliki tujuan untuk menganalisis apakah praktikum yang dilakukan sudah dapat menghadirkan objek atau fenomena yang sedang dipelejari (Kurniasih et al., 2020). Indikator dalam aspek praktikal yang dianalisis meliputi standarisasi dan ketersediaan alat dan bahan yang digunakan dalam pratikum, struktur prosedur kerja, dan juga perekaman data hasil praktikum yang digunakan untuk interpretasi. Hasil analisis terhadap aspek praktikal bisa dilihat pada tabel 2.

Tabel 2. Hasil Analisis Aspek Praktikal

\begin{tabular}{|c|c|c|c|c|c|c|c|c|c|c|}
\hline \multirow{2}{*}{ Indikator } & \multirow{2}{*}{$\begin{array}{l}\text { Skor } \\
\text { maks. }\end{array}$} & \multicolumn{8}{|c|}{ DKL } & \multirow{2}{*}{ Hasil } \\
\hline & & 1 & 2 & 3 & 4 & 5 & 6 & 7 & 8 & \\
\hline $\begin{array}{l}\text { Alat dan Bahan sesuai dengan standar sekolah } \\
\text { dan mudah didapatkan. }\end{array}$ & 3 & 3 & 3 & 3 & 3 & 3 & 3 & 3 & 3 & $100 \%$ \\
\hline Alat dan bahan memiliki satuan yang jelas. & 3 & 3 & 3 & 3 & 3 & 3 & 3 & 3 & 3 & $100 \%$ \\
\hline $\begin{array}{l}\text { Prosedur kerja terstruktur dan tidak menimbulkan } \\
\text { kesalahan. }\end{array}$ & 3 & 2 & 2 & 2 & 3 & 2 & 2 & 3 & 2 & $75 \%$ \\
\hline $\begin{array}{l}\text { Objek dan fenomena muncul dan mudah diamati } \\
\text { melalui prosedur kerja. }\end{array}$ & 3 & 2 & 2 & 2 & 2 & 2 & 2 & 2 & 2 & $66,66 \%$ \\
\hline $\begin{array}{l}\text { Tabel perekaman data sesuai dengan objek } \\
\text { fenomena yang muncul dan mudah di interpretasi. }\end{array}$ & 3 & 3 & 3 & 3 & 2 & 2 & 2 & 3 & 2 & $83,33 \%$ \\
\hline
\end{tabular}


Untuk indikator kemudahan dalam mendapat alat dan bahan menunjukan bahwa 8 DKL yang dianalisis memakai alat dan bahan yang sudah standar laboratorium (berupa kancing genetika) dan mudah untuk didapatkan oleh pihak sekolah, sehingga hasil persentase menunjukan sebesar $100 \%$. Untuk indikator satuan dari alat dan bahan menunjukan bahwa $8 \mathrm{DKL}$ yang dianalisis sudah memiliki keterangan satuan alat dan bahan yang digunakan secara jelas, sehingga hasil persentase menunjukan $100 \%$. Nadia et al., (2020) menjelaskan bahwa ketersediaan alat dan bahan merupakan faktor yang sangat penting, karena jika alat dan bahan tidak tersedia atau rusak maka akan mempengaruhi hasil dari kegiatan praktikum. Supriatno (2018) menjelaskan bahwa sebagian alat dan bahan yang dicantumkan pada LKPD yang tersebar dibeberapa sekolah tidak memperhatikan ketersedian yang ada di sekolah tersebut, hal ini disebabkan karena LKPD yang dipakai hanya mengadopsi prosedur dari LKPD yang sudah ada tanpa dilakukan pengecekan terlebih dahulu. Untuk indikator prosedur kerja menunjukan bahwa 2 DKL sudah memiliki prosedur kerja yang jelas dan dilengkapi dengan ilustrasi, namun untuk $6 \mathrm{DKL}$ lainnya prosedur kerjanya tidak disertai dengan ilustrasi, sehingga hasil persentase menunjukan sebesar $75 \%$. Untuk indikator objek dan fenomena yang muncul melalui langkah kerja menunjukan hasil bahwa 8 DKL yang dianalisis memiliki beberapa langkah kerja yang mengarahkan siswa untuk mengamati objek dan fenomena, sehingga hasil persentase menunjukan sebesar $66,66 \%$. Untuk indikator tabel perekaman data menunjukan bahwa $4 \mathrm{DKL}$ yang dianalisis sudah memiliki tabel perekaman data yang dapat merekam seluruh objek/fenomena, namun untuk 4 DKL lainnya tabel perekaman data hanya merekam sebagian objek atau fenomena saja, sehingga persentase hasil menunjukan sebesar $83,33 \%$.

\section{Aspek Kontruksi Pengetahuan}

Analisis kontruksi pengetahuan bertujuan untuk menganalisis apakah objek atau fenomena yang terdapat pada LKPD sudah dapat mengarahkan siswa pada kontruksi pengetahuan (Deratama et al., 2020). Indikator yang dianalisis pada aspek kontruksi pengetahuan meliputi (1) judul/tujuan/pertanyaan fokus, (2) objek fenomena, (3) teori/prinsip dan konsep, (4) perekaman data dan transformasi data, (5) perolehan pengetahuan. Menurut Hasil analisis aspek kontruksi pengetahuan bisa dilihat pada tabel 3 .

Tabel 3. Hasil Analisis Aspek Kontruksi Pengetahuan

\begin{tabular}{c|c|c|c|c|c|c|c|c|c|c}
\hline Indikator & Skor & \multicolumn{7}{|c|}{ DKL } & \multirow{2}{*}{ Hasil } \\
\cline { 3 - 13 } & maks. & 1 & 2 & 3 & 4 & 5 & 6 & 7 & 8 & \\
\hline Judul/Tujuan/Pertanyaan fokus & 3 & 2 & 2 & 2 & 1 & 1 & 2 & 2 & 2 & $58,33 \%$ \\
\hline Objek fenomena & 3 & 2 & 1 & 2 & 2 & 1 & 2 & 2 & 2 & $58,33 \%$ \\
\hline Teori, prinsip, dan konsep & 4 & 2 & 2 & 2 & 2 & 2 & 2 & 2 & 2 & $50 \%$ \\
\hline Perekaman dan transformasi data & 4 & 2 & 2 & 2 & 2 & 2 & 2 & 2 & 2 & $50 \%$ \\
\hline Perolehan pengetahuan & 4 & 3 & 3 & 3 & 3 & 3 & 3 & 3 & 3 & $75 \%$ \\
\hline
\end{tabular}

Menurut Nadia et al., 2020) suatu LKPD dikatakan memiliki aspek kontruksi pengetahuan yang kurang jika (1) tidak bisa memunculkan objek/fenomena dari materi yang sedang dipelajari, (2) pencatatan data hasil observasi tidak tersedia atau tidak sesuai (3) tidak mengarahkan siswa untuk melatih kemampuannya dalam melakukan transformasi data, (4) langkah atau prosedur pada LKPD tidak dapat memunculkan konsep/teori/prinsip mengenai materi yang sedang dipelajari. Untuk indikator judul/tujuan/pertanyaan fokus menunjukan bahwa $6 \mathrm{DKL}$ telah mengandung konsep yang terdapat pada judul/pertanyaan fokus/tujuan, namun ada 2 DKL yang memiliki judul/tujuan/pertanyaan fokus tetapi 
belum bisa mengarahkan pada objek utama pada bagian konseptual, sehingga hasil presentease menunjukan $58,33 \%$. Untuk indikator objek/fenomena menunjukan bahwa 6 DKL telah mengarahkan pada peristiwa utama yang disertai objek/fenomena yang dapat di identifikasi, namun ada 2 DKL yang memiliki objek/fenomena yang tidak konsisten dengan pertanyaan fokus, sehingga hasil persentase menunjukan 58,33\%. Untuk indikator teori,prinsip dan juga konsep menunjukan bahwa 8 DKL yang di analisis sudah terdapat beberapa konsep dan teori yang disertai dengan prinsip, sehingga hasil persentase menunjukan $50 \%$. Untuk indikator perekaman data dan transformasi data menunjukan bahwa $8 \mathrm{DKL}$ yang dianalisis sudah memiliki perekaman data dan juga mengarahkan siswa untuk melakukan transformasi data, sehingga hasil presentasi menunjukan 50\%. Untuk Indikator perolehan pengetahuan menunjukan bahwa $8 \mathrm{DKL}$ sudah mengarahkan siswa terhadap perolehan pengetahuan yang mengandung konsep-konep yang sudah sesuai dengan pertanyaan fokus, sehingga hasil persentase menunjukan $75 \%$. Setelah melakukan analisis terhadap LKPD berdasarkan aspek konseptual, praktikal dan juga kontruksi pengetahuan, maka langkah selanjutnya adalah dengan melakuakn uji coba kelayakan dari LKPD. Berdasarkan uji coba yang diilakukan maka didapatkan hasil yang tercantum pada tabel 4 .

\section{Tabel 4. Hasil Uji Coba LKPD}

\begin{tabular}{|c|c|}
\hline Permasalahan Yang Ditemukan & Alternatif Solusi \\
\hline $\begin{array}{l}\text { Waktu pelaksanaan praktikum pada LKDP tidak tercantum, } \\
\text { sehingga terjadi keterlambatan dan melebihi alokasi waktu. }\end{array}$ & $\begin{array}{l}\text { Alokasi waktu dicantumkan pada LKPD, sehinnga waktu } \\
\text { pelaksaanaan lebih efektif dan efisien. }\end{array}$ \\
\hline $\begin{array}{l}\text { Pada langlah kerja terdapat penjelasan ambigu berupa } \\
\text { kancing genetika cekung dan cembung yang dapat } \\
\text { membuat siswa tidak bisa membedakan antara satu } \\
\text { kancing genetika dengan kancing genetika yang laiinya. }\end{array}$ & $\begin{array}{l}\text { Perubahan pada langkah kerja dengan mengganti istilah } \\
\text { kancing genetika cembung dan cekung menjadi kancing } \\
\text { genetika yang memiliki kuncian dengan yang tidak } \\
\text { memiliki kuncian }\end{array}$ \\
\hline $\begin{array}{l}\text { Pada langkah kerja tidak ada instruksi untuk menutup mata } \\
\text { ketika mengambil kancing genetika secara acak. }\end{array}$ & $\begin{array}{l}\text { Pada langkah kerja dicantumkan instruksi untuk menutup } \\
\text { mata dengan kain. }\end{array}$ \\
\hline $\begin{array}{l}\text { Pertanyaan diskusi pada LKPD hanya menanyakan hasil } \\
\text { perbandingan genotip dan fenotip saja, sehinnga } \\
\text { pertanyaan diskusi bersifat lower order thinking }\end{array}$ & $\begin{array}{l}\text { Pada LKPD akan dimunculkan pertanyaan disksusi yang } \\
\text { bersifat high order thinking skill (HOTS) berdasarkan } \\
\text { praktikum yang dilakukan. }\end{array}$ \\
\hline
\end{tabular}

\section{Rekontruksi LKPD Yang Diharapkan}

Rekontruksi dilakukan untuk melengkapi kekurangan-kekurangan yang ada pada 8 DKL yang telah dianalisis berdasarkan 3 aspek yang sudah dijelaskan, yaitu aspek konseptual, aspek praktikal dan aspek kontruksi pengetahuan. Kurniasih et al., (2020) menjelaskan bahwa ada 8 unsur utama dari sebuah LKPD yaitu (1) judul, (2) kompetensi yang ingin dicapai, (3) waktu pelaksanaan praktikum, (4) alat dan bahan yang digunakan, (5) instruksi pengerjaan, (6) Prosedur kerja, (7) tugas yang harus dikerjakan (8) laporan yang harus dikerjakan.

Berdasarkan hasil analisis yang telah dilakukan terhadap $8 \mathrm{DKL}$, penulis membuat LKPD yang disesuaikan dengan kompetensi dasar terdapat pada kurikulum 2013 (kurtilas), yaitu KD 3.5 yang berbunyi "Menerapkan prinsip pewarisan sifat makhluk hidup berdasarkan hukum mendel: dan KD 4.5 yang berbunyi "Menyajikan hasil penerapan hukum Mendel dalam perhitungan peluang dari persilangan makhluk hidup dibidang peternakan dan pertanian". Selanjutnya beberapa aspek yang masih belum lengkap dalam aspek praktikal seperti keterangan satuan alat dan bahan yang tidak dicantumkan pada beberapa DKL diperbaiki pada rekontruksi DKL yang dibuat. Kekurangan berdasarkann hasil analisis selanjutnya yang penulis coba perbaiki adalah langkah kerja. Pada beberapa DKL langkah kerja yang dicantumkan belum terstruktur dengan baik dan belum sistematis, sehingga pada rekontruksi DKL yang dibuat penulis mencoba membuat DKL dengan langkah kerja yang terstruktur dan sistematis yang 
dapat memunculkan objek atau fenomena dari konsep yang dipelajari. Selanjutnya indikator tabel perekaman data masih terdepat kelemahan, pada beberapa DKL tabel perekaman data belum bisa merekam semua data dari objek dan fenomena yang disajikan pada praktikum karena masih terdapat DKL yang memiliki tabel perekaman data yang tidak sesuai.

Pada indikator interpretasi data dan transformasi data pada 8 DKL yang dianalisis masih menunjukan bahwa kegiatan praktikum yang dilaksanakan belum mengarahkan siswa untuk melakukan interpretasi data yang baik dan untuk transformasi data beberapa DKL hanya mengarahkan siswa untuk menyajikan data hasil penelitian dalam bentuk standar yaitu berupa tabulasi, frekuensi dan perbandingan. Untuk level kemampuan berpikir menunjukan bahwa 7 DKL hanya mengarahkan untuk berpikir level C3 (mengaplikasikan) dan 1 DKI mengarahkan pada berpikir level C4 (menganalisis), 7 DKL yang dianalisis masih tergolong hanya mengarahkan siswa pada tingkat berpikir level rendah/lower order thinking skill (LOTS). Kekurangan selanjutnya adalah pada 8 DKL yang dianalisis judul/tujuan/pertanyaan fokus, belum memfokuskan kepada hal utama yang berkaitan dengan objek dan peristiwa atau tidak mengandung bagian konseptual terutama prinsip.

Adapun rekonstruksi LKPD yang ditawarkan sebagai solusi dari tidak sesuaian LKPD praktikum kancing genetika berdasarkan hasil analisis dan juga uji coba adalah sebagai berikut:

\section{PERSILANGAN MONOHIBRID DAN DIHIDRID DENGAN MENGGUNAKAN KANCING GENETIKA}

Bagaimanakah karakteristik dari persilangan monohibrid dan dihibrid? Faktor apa saja yang mempengaruhi persilangan monohibrid dan dihibrid?

NAMA :

TUJUAN

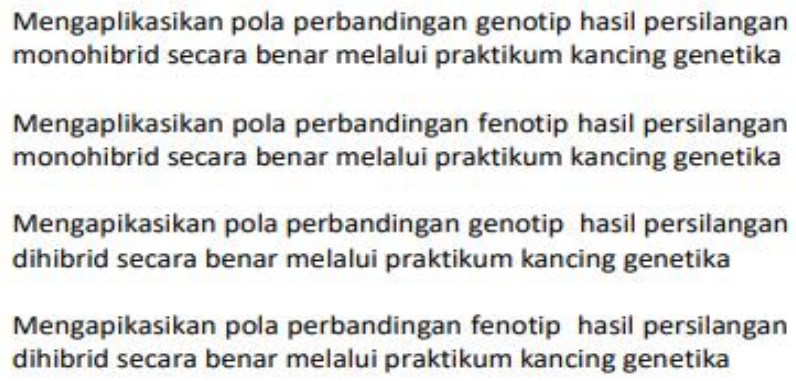

Mengaplikasikan pola perbandingan genotip hasil persilangan monohibrid secara benar melalui praktikum kancing genetika

Mengaplikasikan pola perbandingan fenotip hasil persilangan monohibrid secara benar melalui praktikum kancing genetika

Mengapikasikan pola perbandingan genotip hasil persilangan dihibrid secara benar melalui praktikum kancing genetika

Mengapikasikan pola perbandingan fenotip hasil persilangan dihibrid secara benar melalui praktikum kancing genetika

WAKTU PELAKSAAN : $2 \times 45$ menit

ALAT DAN BAHAN :

1 Set Kancing Genetika

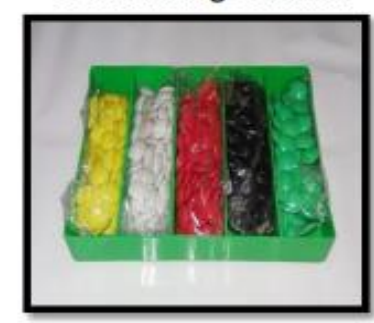

6 Buah Toples

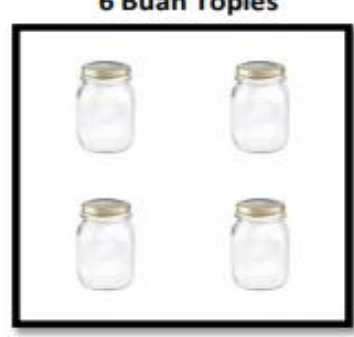




\section{Persilangan monohibrid}

\section{PROSEDUR KERJA}

1. Siapkan kancing genetika dengan 2 macam warna yang berbeda, masing-masing warna sebanyak 50 buah kancing genetika

2. Ketentuan alel setiap warna kancing adalah sebagai berikut:

a. Warna $1(\mathrm{H})$ dengan fenotip warna Hitam

b. Warna 2 (h) dengan fenotip warna Putih

c. alel dengan huruf kapital merupakan gen dominan dan alel dengan huruf non-kapita merupakan gen resesif

3. Pisahkan kancing genetika tersebut berdasarkan bentuk (ada yang memiliki kuncian dan tidak memiliki kuncian), lalu pindahkan ke toples khusus 1 untuk kancing genetika yang memiliki kuncian dan toples 2 kancing genetika yang tidak memiliki kuncian

4. Ambil lah masing-masing kancing genetika dari toples 1 dan toplas 2 secara acak tanpa melihat

5. Catatlah hasil pengambilan pasangan kancing dari toples 1 dan toples 2

6. Ulangi langkah $\mathbf{4}$ dan 5 sampai kancing genetika pada toples 1 dan toples 2 habis.

\section{Persilangan Dihibrid}

1. Siapkan kancing genetika yang terdiri atas 4 warna, masing masing warna sebanyak 50 buah.

2. Ketentuan alel setiap warna kancing adalah sebagai berikut:

a. Warna $1(\mathrm{H})$ dengan fenotip bentuk bulat,

b. Warna 2 (h) dengan fenotip bentuk keriput

c. Warna 3 (K) fenotip warna kuning,

d. Warna 4 (k) untuk fenotip warna kuning

e. alel dengan huruf kapital merupakan gen dominan dan alel dengan huruf non-kapital merupakan gen resesif

3. Menyiapkan 50 buah kancing genetika warna 1 yang memiliki kuncian dan 50 buah kancing genetika warna 2 yang memiliki kuncian ke dalam toples I,

4. Menyiapkan 50 kancing genetika warna 1 yang tidak memiliki kuncian dan 50 buah kancing genetika warna 2 yang tidak memiliki kuncian ke dalam toples II,

5. Menyiapkan 50 buah kancing genetika warna 3 yang memiliki kuncian dan 50 buah kancing genetika warna 4 yang memiliki kuncian ke dalam toples III,

6. Menyiapkan $\mathbf{5 0}$ buah kancing genetika warna 3 yang tidak memiliki kuncian dan $\mathbf{5 0}$ buah kancing genetika warna 4 yang tidak memiliki kuncian ke dalam toples IV,

7. Ambilah secara acak kancing genetika dari toples I dengan toples II tanpa melihat

8. Ambilah secara acak kancing genetika dari toples III dan toples IV tanpa melihat

9. Catatlah pasangan kancing genetika yang berasal dari toples I dan toples II dengan pasangan kancing genetika yang berasal dari toples III dan toples III.

10. Ulangi langkah 7 sampai dengan langkah 9 sampai setiap kancing genetika pada toples I,II,III dan IV habis.

Persilangan monohibrid

HASIL PERCOBAAN

\begin{tabular}{|c|c|c|}
\hline Pasangan Gen & Tabulasi & Frekuensi \\
\hline & & \\
\hline & & \\
\hline & & \\
\hline
\end{tabular}


Persilangan dihybrid

\begin{tabular}{|c|c|c|c|}
\hline Genotip & Fenotip & Tabulasi & Frekuensi \\
\hline & & & \\
\hline & & & \\
\hline & & & \\
\hline & & & \\
\hline & & & \\
\hline & & & \\
\hline & & & \\
\hline & & & \\
\hline
\end{tabular}

\section{PERTANYAAN DISKUSI}

1. Bagaimanakah perbandingan genotip dan fenotip pada persilangan monohibrid yang didapat berdasarkan praktikum?

2. Apa yang menyebabkan persilangan monohibrid menghasilkan perbandingan tersebut pada saat praktikum?

3. Bagaimana perbandingan genotip dan fenotip pada persilangan dihibird yang didapatkan berdasarkan praktikum?

4. Apa yang menyebabkan persilangan dihibrid menghasilkan perbandingan tersebut pada saat praktikum?

5. Apakah terdapat perbedaan hasil pada praktikum persilangan monohibrid dengan persilangan dihibrid? Jika terdapat perbedaan, maka jelaskanlah perbedaan tersebut berdasarkan praktikum yang telah dilakukan!

6. Buatlah laporan hasil praktikum persilangan monohybrid dan dihibrid dalam bentuk powerpoint untuk dipresentasikan!

\section{SIMPULAN}

Berdasarkan hasil uji coba dan analisis terhadap LKPD berdasarkan aspek konseptual, aspek, aspek praktikal dan aspek kontruksi pengetahuan mengenai materi praktikum kancing genetika ditemukan beberapa ketidaksesuaian dan kekurangan pada beberapa indikator yang ada pada ketiga aspek tersebut. Sehingga berdasarkan kekurangan dan ketidaksesuaian tersebut perlu diadakannya rekonstruksi ulang terhadap LKPD agar ketika digunakan siswa tidak akan menimbulkan kesalahan dalam pemahaman siswa (miskonsepsi) dan agar praktikum lebih efektif dan efisien. Rekonstruksi LKPD praktikum kancing genetika hasil rekontruksi diharapkan menjadi alternatif LPKD untuk melengkapi kekurangan LKPD yang ada pada saat ini.

\section{RUJUKAN}

Abidin, Y. (2016). Desain Sistem Pembelajaran Dalam Konteks Kurikulum 2013 (3rd ed.). Refika Aditama.

Aisya, N. S. M., Saefudin, Supriatno, B., \& Anggraeni, S. (2016). Penerapan Diagram Vee dalam Model Pembelajaran Inquiry Lab dan Group Investigation untuk Meningkatkan Kemampuan Literasi Kuantitatif Siswa Kelas VII pada Materi Pencemaran Lingkungan Application of Vee Diagram Learning Strategy Through Inquiry Lab and Gro. Proceeding Biology Education Conference, 13(1), 112-117.

Anderson, L. W., \& Krathwohl, D. R. (2015). Pembelajaran, Pengajaran, dan Asesmen (1st ed.). Pustaka Pelajar.

Astika, E., Anggraeni, S., \& Supriatno, B. (2020). Analisis Komponen Penyusun Desain Kegiatan 
Laboratorium Enzim Katalase. Biodik, 6(3), 343-356. https://doi.org/10.22437/bio.v6i3.9469

Deratama, D., Sri Anggraeni, \& Bambang Supriatno. (2020). Analisis Komponen Penyusun Lembar Kerja Siswa Biologi SMA Pada Praktikum Uji Enzim Katalase. Biodik, 6(3), 299-309. https://doi.org/10.22437/bio.v6i3.9513

Hergenhahn, B. ., \& Olson, M. (2012). Theories of Learning (7th ed.). Kencana Prenada Media Grup.

Holstermann, N., Grube, D., \& Bögeholz, S. (2010). Hands-on Activities and Their Influence on Students' Interest. Research in Science Education, 40(5), 743-757. https://doi.org/10.1007/s11165-009-9142-0

King, F. J., Goodson, L., \& Rohani, F. (2017). Assessment \& Evaluation: Higher Order Thinking Skills. Center for Advancement of Learning and Assessment, 18, 176. http://www.cala.fsu.edu/files/higher_order_thinking_skills.pdf

Kurniasih, W., Sri Anggraeni, \& Bambang Supriatno. (2020). Alternatif Lembar Kerja Peserta Didik Materi Osmosis Berbasis ANCORB. Biodik, 6(3), 266-276. https://doi.org/10.22437/bio.v6i3.9451

Millar, R. (2004). The role of practical work in the teaching and learning of science. October.

Muriani, A. S. (2017). Genetika Dengan Media Kancing Menggunakan Model Numbered Head Together ( NHT ) Improving Student Learning Activities in Genetic Materials with a Buttons Media Using Numbered Head Together ( NHT ) Model. Jurnal Inovasi Pendidikan Sains, 8(1), 13-26.

Nadia, N., Supriatno, B., \& Anggraeni, S. (2020). Analisis dan Rekonstruksi Komponen Penyusun Lembar Kerja Peserta Didik Struktur dan Fungsi Jaringan Tumbuhan. Biodik, 6(2), 82-94. https://doi.org/10.22437/bio.v6i2.9439

Novak, J. D., \& Gowin, D. B. (1984). Learning How To Learn (21st ed.). Cambrigde University Press.

Putri, A. F. (2016). Pengembangan Lembar Kerja Siswa (Lks) Sebagai Bahan Ajar Siswa Kelas X Jasa Boga Smk Muhammadiyah 1 Moyudan Proposal Skripsi. Universitas Negeri Yogyakarya.

Rustaman, N. Y. (2017). Mewujudkan Sistem Pembelajaran Sains/Biologi Berorientasi Pengembangan Literasi Peserta Didik. Jurnal Universitas Muhamadiyah Malang, April, 1-8.

Slameto. (2015). Belajar dan Faktor-Faktor Yang Mempengaruhi. Rineka Cipta.

Sugiyono. (2017). Metode Penelitian Kualitatif,Kuantitaif, dan R\&D. Alfabeta.

Supriatno, B. (2013). Pengembangan program perkuliahan pengembangan praktikum biologi sekolah berbasis ANCORB untuk mengembangkan kemampuan merancang dan mengembangkan desain kegiatan laboratorium (Doctoral dissertation). Universitas Pendidikan Indonesia.

Supriatno, B. (2018). Praktikum untuk Membangun Kompetensi. Proceeding Biology Education Conference, 15(1), 1-18.

Tawil, M., \& Liliasari. (2013). Berpikir Kompleks. Badan Penerbit Universitas Makasar.

Wahidah, N. S., Supriatno, B., \& Anggraeni, S. (2018). Analisis Struktur dan Kemunculan Tingkat Kognitif pada Desain Kegiatan Laboratorium Materi Fotosintesis. Indonesian Journal of Biology Education, 7260(2), 70-76. 